\title{
Lean Concepts Stream Mapping of Gear Manufacturing
}

\author{
G. Yuvaraj, K. Giritharan, Radhika Koganti, R.S. Kumar, R. Ramadoss
}

\begin{abstract}
India has increasing demand for wind energy. The potential energy that can be generated by using wind energy is around 15000-20000 MW but now only $600 \mathrm{MW}$ is utilized. The demands of wind turbines are significantly high in the present market scenario. Lead time of the producing wind mill components is a most critical in satisfying customer demands. This project is an attempt to apply lean principles and methodologies in the component section of a wind mill gear box manufacturing industry and to identify non value added activities and to eliminate them and to improve the productivity and profit of the industry by reducing the lead time of the component. Hansen drives limited, a case study industry created with a goal to become the global benchmark for quality wind mill gear box by using recent technology, effective processes for meeting customer demand. The industry was not able to meet the customer demand due to the increasing cycle time of the individual process. More processing time occurs in torque arm component and planet shaft component section of the production unit that results in increase in production time and inventory. The machine shop of a wind mill component manufacturing section in gearbox manufacturing industry is analyzed by using value stream mapping tool to identify the waste present in the current process and to eliminate them from the manufacturing process by using required lean tool for the future improvements in reducing the lead time of the product and to improve the productivity to meet customer demands.
\end{abstract}

Keywords: Lean Manufacturing, Lean assembly line, Lean rate, Value stream

\section{INTRODUCTION}

The aim of the lean manufacturing System (LMS) is to identify the wastages / problems / suggestion for the improvements and improve upon the same to improve the customer satisfaction and the applications of the tools and techniques of LMS insist the industries to utilize the existing resources efficiently and effectively. Lean production also known as lean manufacturing has been extensively applied by many manufacturing companies around the world. It has produced many positive outcomes such as reduced cycle time, reduction in cost, waste and defects. The objective of lean manufacturing is to produce the same output with less input, less time, less space, less human effort and so on. Lean manufacturing aims to eliminate seven wastages from manufacturing environment are overproduction, inventory over processing, waiting time, unwanted motion, defects and transportation (Mekong, (2005). The main reason why the companies choose to outsource or move their operations

Revised Manuscript Received on 14 September, 2019.

G. Yuvaraj, Mechanical Engineering, Easwari Engineering College, Chennai, Tamilnadu, India. (Email: yuvarajg75@gmail.com)

K. Radhika, Mechanical Engineering, Easwari Engineering College, Chennai, Tamilnadu, India, (Email: radhika.k@eec.srmrmp.edu.in)

Dr. R. S. Kumar, Mechanical Engineering, Easwari Engineering College, Chennai, Tamilnadu, India, (Email: rs_kmr@yahoo.com)

Dr. R. Ramadoss, Mechanical Engineering, Easwari Engineering College, Chennai, Tamilnadu, India, (Email: drramadoss@gmail.com) overseas is due to increasing labor cost. So these companies move their operations to developing countries where the wages and the production costs are low. So to reduce the cost and to be competitive with the companies whose operations are in overseas, they choose lean manufacturing. The main objective of lean manufacturing is to reduce the waste by employing certain tools and methodologies. After studying the theory of LMS tools and techniques, the concepts of LMS have been implemented in a gear box manufacturing industry to improve the effective utilization of the resources and improve the efficiency of their products. The works reported in this project is an important technique leading to investigation and improvements towards productivity and lead time reduction in the gear box manufacturing industry to meet their customer demands.

\section{LITERATURE SURVEY}

Nahmias (2011), proposed that the base of lean manufacturing is to eliminate the waste and the pillars of lean manufacturing is Just in time and automation with human touch. The objective of just in time is to produce the right part at the right place and at the right time. So this reduces the waste such as physical damages and the defects. Shingo (2009), described that the principle of kaizen or continuous improvement process is to reduce the waste. The process that does not contribute to operation is called as waste. Value adding process (welding, forming, etc) is defined as an activity which transforms the raw material into the finished goods. Shook (2012), Value steam mapping is defined as a tool or an activity that collects all value added process and non-value added process that is required for transforming a raw material into the finished goods. Mitrofanov (2014), cellular manufacturing is a concept where similar products are grouped in to part families, not only according to their manufacturing similarities but also arranges machines in to machine cells based on the parts manufactured by them. Aslo, group technology (GT) philosophy, which is a management theory that looks to group products with similar processes, manufacturing attributes, or both. Monden (2015), 5S is the first modular approach to serious waste production. $5 \mathrm{~S}$ is made up of the Japanese words seiri (sort), seiton (straighten), seiso (sweep and clean), seiketsu (systemize), and shitsuke (standardize). The concept behind $5 \mathrm{~S}$ is to look for waster and then try to eliminate it. Waste could be in any form such as scrap, 
defects, excess raw material, unneeded items, old broken tools, and obsolete jigs and fixtures.. Carter and Fawcett (2015),multiskilled managers and workers are the key components of a lean manufacturing organization, In addition to cross-functional training, companies can influence even the level of multiskilling by establishing norms for the organization and procedures supporting it. Further research into the impacts of cross-skilled managers is required. Hines and Taylor (2016), the lean manufacturing technique is to work in every facet of the value stream by the elimination of waste in order to, reduce cost, generate capital, bring more sales and remain competitive in the growing global market. Sweeny (2016),5S means goods housekeeping and better organization of the workplace. Kaizen tools such as $5 \mathrm{~S}$ are not only a way to increase the profitability of a firm but also allow companies to show potential strengths and capabilities that were hidden before. Based on the literature review, it can be concluded that the lean manufacturing has been used all over the world many years ago, in the Indian context, most of the organizations started introducing lean concepts currently that too with the proliferation of VSM in India, is found to be feasible.

\section{Description of the Product}

To meet the speed requirements for the power generation process the shaft mounted speed reducer is one of the possible way. The shaft mounted speed reducer is directly mounted onto steel shaft directly. Process study of wind mill component for torque arm component has been studied from the raw material entry to dispatch of component through assembly section. The reason behind the selection of this component is that they are less weight and can be easily assembled or disassembled for the usage. The torque component is shown in the figure 1

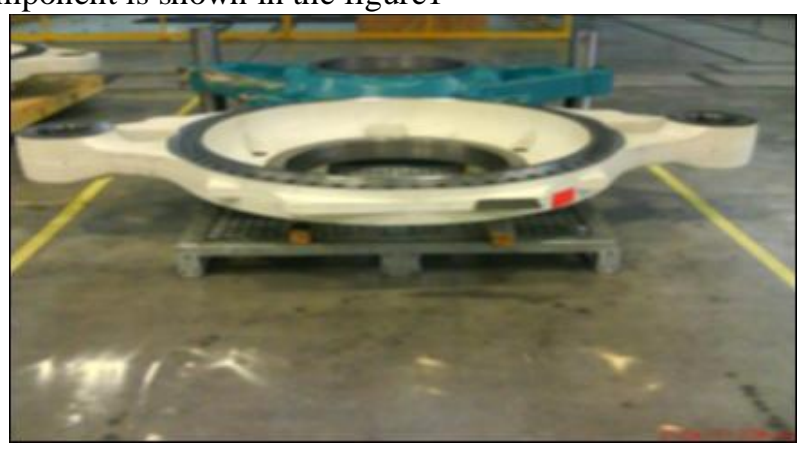

Figure 1. Torque arm component

\section{Torque arm component process details}

The raw casting from the ware house is delivered to the machine shop through the pallet truck. In the machine shop, the casting should be shaped into four operations to get the final component. They are operation 10, operation 20, operation 30 and operation 40. The operation 10 (facing, drilling, thread milling, tapping, boring) machining processes are carried out in vertical machining centre (machine name- okuma), these operation are carried out by the single operator. The loading and unloading of the component is done by the overhead cranes in the shop floor. The next operation 20 is an NDT inspection so the component is transferred from the machine shop to the inspection area by the pallet truck. where the two NDT inspections are carried out (magnetic particle testing and

ultrasonic testing) by the two operators, then the component is brought back to the machine shop for operation 30.In the operation 30, the sequences of machining operation are carried out are (turning, face milling, boring, drilling, chamfering and tapering) in machining Centre(machine name-dorries)after that the component is again transferred to inspection area for NDT inspection for operation 40.Then finally the finished torque arm component is dispatched to the assembly section. The raw casting component is processed in each cell in the layout to obtain final torque arm finished component. In the torque arm cell layout there are two Okuma machining center and two Dorries machining center are present in the shop floor and the inspection cell is separately placed from the torque arm cell layout. The first operation is begins with operation 10 (facing, drilling, thread milling, tapping, boring), machining operation are carried out in the okuma machine (vertical machining center), then the semi-finished component is moved to the inspection area for operation 20(NDTinspection) through the pallet truck as per the pathway shown in the figure 3. After the completion of operation 20 then the component is brought back to the cell for the next operation 30.In the operation 30 remaining machining process are carried in Dorries machine(machining center) are(turning, face milling, boring, drilling, chamfering and tapering) to complete the machining process involved in the torque arm component, again the component is moved inspection area for final inspection operation 40(NDTinspection).the NDT-inspection are (magnetic particle testing and ultrasonic testing).then finally the finished component is dispatched to assembly section.

\section{DEVELOPMENT OF CURRENT STATE MAP \& RESULTS}

The map representing the current state development for the torque arm is shown in figure 2 . The orders are first received from the customer on a monthly basis. The customer demands are changed throughout the year with some fluctuations. About 30 torque arm shafts are demanded by the customers (assembly section) each month. The production control department gives out instructions to various personnel on a weekly basis. A total of four processes are involved in manufacturing the torque arm. The company operates on two shifts per day, each shift of nine hours duration with 30-minute lunch break per day (each shift of nine- hour's duration with 30- minute lunch break per shift and 5- minute tea break per shift and company operate on 20 days in month. The data collected from time study the current state VSM has been created using Microsoft Visio template.

\section{*Calculation of Takt Time}

Takt time $=\underline{\text { Total time available for production per shift }}$ Required numbers of parts per shift 


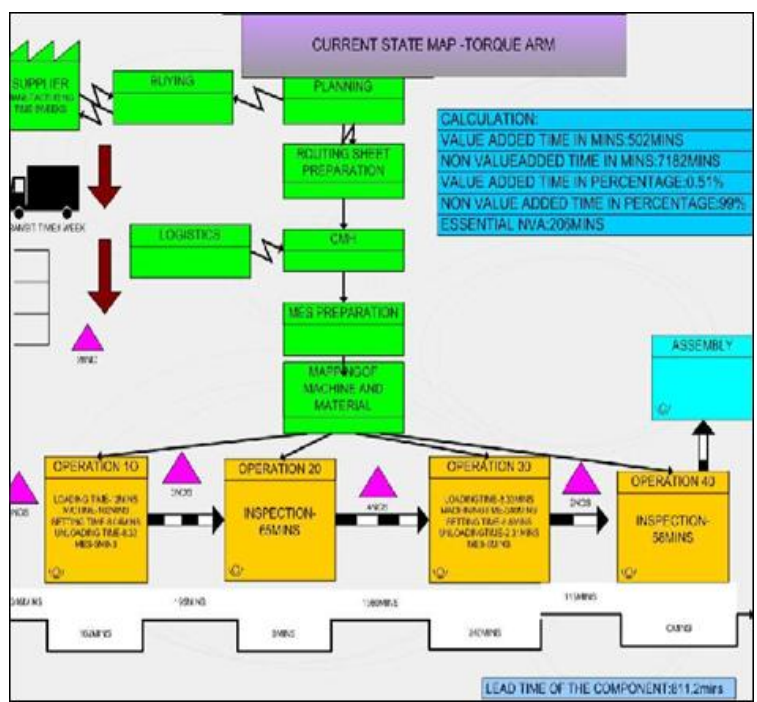

Figure 2. Current state VSM for torque arm component

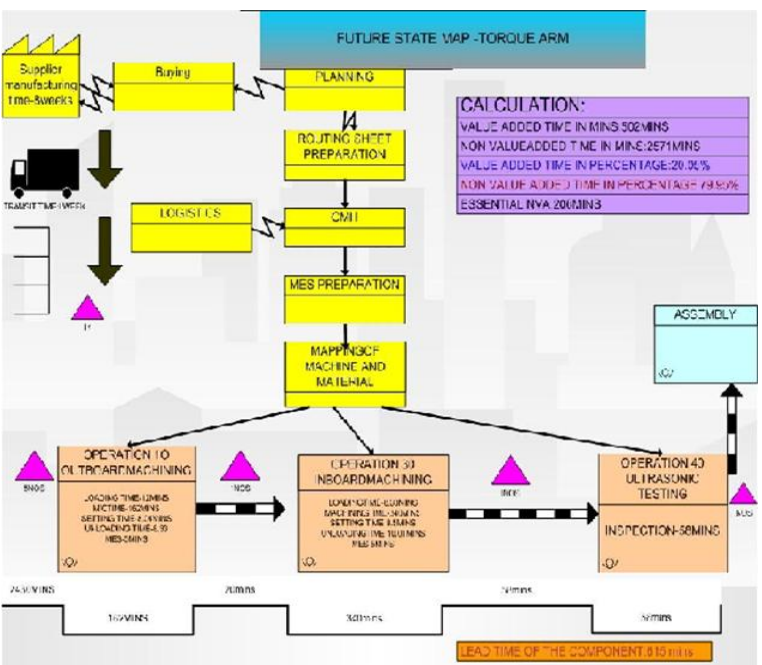

Figure 3. Future state VSM for torque arm component

Networking time per shift $=$ [available time-(break + break down)]

$=505-35=470$ minutes $=28200$ seconds

Networking time per month $=1128000$ seconds

Customer demand per day $=30$ pieces

Takt time $=1128000 / 30$

Takt time $=626.66$ minutes

\section{Analysis of current state VSM for torque arm component}

In the analysis of current state VSM of torque arm component operation processes are operation 10, operation 20, operation 30 and operation 40.In this operation 10 and operation 30 are machining processes and operation 20 and operation 40 NDT inspection processes is 24 Magnetic particle testing.

It's a method in which the discontinuities are detected, these are primarily located linear to the surface of ferromagnetic components and it's structure. Ultrasonic testing is used to detect the material inner defect. After the analysis of current state VSM of torque arm component identified waste and its time duration are shown in table 1.
Table 1. Wastes and time duration for torque arm component

\begin{tabular}{|c|c|c|}
\hline S.NO & Waste Identified & $\begin{array}{c}\text { Time Duration } \\
\text { (Minutes) }\end{array}$ \\
\hline 1 & $\begin{array}{c}\text { Inspection } \\
\text { (operation20) }\end{array}$ & 65 \\
\hline 2 & $\begin{array}{c}\text { Filling of coolant } \\
\text { oil }\end{array}$ & 20 \\
\hline 3 & $\begin{array}{c}\text { Transportation } \\
\text { and waiting time }\end{array}$ & 30 \\
\hline & Total & 115 \\
\hline
\end{tabular}

In this case of torque arm component the two inspection test (magnetic particle testing and ultrasonic testing) are already carried out in the supplier point itself inspected and tested before shipping of raw casting to the industry. So doing more work on a part than is necessary, including inspection and reworking is wastes time and money is termed as over processing waste in lean manufacturing system. So the operation 20 should be eliminated from the current processes for future development. The magnetic particle test can be identified clearly in raw material stage itself but in case ultrasonic testing inspection defect cannot be $100 \%$ identified in raw material stage accurately. So after the completion of final machining the ultrasonic inspection should be carried out in the processes sequence of torque arm component to clear vision of defect.

The second waste identified is idle time of machine due to filling of coolant oil into the machine for lubrication purpose during metal cutting processes which may cause 30 minutes idle time of machine and operator, it may increase the machine down time as well as lead time of the component and production cost. The third waste identified was irregular flow of material between each operation because distance between each machines and inspection department section are very high, which increases the transportation cost, production cost and lead time of the product. The non-valueadded time identified as per the table 2 is about $115 \mathrm{mins}$, it should be eliminated in the future state map of torque arm component.

\section{Proposal for future state VSM for torque arm component}

The future state map depicts the various modifications incorporated in the manufacturing processes of the torque arm component at Hansen drives. After the analysis of wastes existing in the manufacturing processes of the torque arm, it provides various methods for waste elimination, that have been developed in consultation with the production manager which are presented as Elimination of operation 20 from the processes sequence of torque arm component, by rearrange the processes sequence by caring out the magnetic particle test should be carried before operation 10 in case of raw material stage, and the ultrasonic test should be carried out after the final machining processes(operation 30) The filling of coolant oil in the machine for lubrication purpose during metal- 
cutting operation can be done while loading and setting of the component in the fixture by the operator, which reduces the 30- minute machine idle time and operator idle time. Implementation of cellular manufacturing system in the torque arm cell layout by placing machines closely together according to the processes sequence. The inspection section should be made to the torque arm cell layout itself to reduce the material handling cost, transportation cost and lead time of the product is shown in table 2 . To improve the flexibility of the material flow and to reduce work in processes inventory.

\begin{tabular}{|l|c|c|c|}
\hline Component & $\begin{array}{c}\text { Before } \\
\text { improvement }\end{array}$ & $\begin{array}{c}\text { Proposed } \\
\text { improveme } \\
\text { nt }\end{array}$ & $\begin{array}{c}\% \\
\text { efficiency } \\
\text { increase }\end{array}$ \\
\hline Lead- time & $811.2 \mathrm{mins}$ & $615.21 \mathrm{mins}$ & $24.56 \%$ \\
\hline $\begin{array}{l}\text { Non-value } \\
\text { added time } \\
\text { (decrease) }\end{array}$ & $7182 \mathrm{mins}$ & $2571 \mathrm{mins}$ & $64.22 \%$ \\
\hline $\begin{array}{l}\text { Production } \\
\text { of } \\
\text { component } \\
\text { per month }\end{array}$ & 25 (numbers) & $\begin{array}{c}30 \\
\text { (numbers) }\end{array}$ & $16.66 \%$ \\
\hline
\end{tabular}

Table 2. Proposed improvement for the torque arm component

\section{CONCLUSIONS}

The manufacturing organizations are adopting new manufacturing archetype due to various factors affecting the product complexity and market turbulence. The aim of Lean manufacturing is to reconfigure and remodel the business processes based on elimination of wastes, and thus enabling cost reduction. One of the most important technique used in the operation of manufacturing is "VALUE STREAM MAPPING" .This project work reports a case study that is focused on the implement of VSM for wind mill component manufacturing unit of wind mill gear box manufacturing industry. Various concepts from the stand of leanness improvement namely 5S, waste eliminations and line balancing, have been derived. It has been found that the implementation of these concepts have contributed to the significant reduction of processing time, total lead time, improvement in production rate, reduced defects as well as appreciable improvement on- time delivery. VSM is an lean manufacturing Technique, which is effectively used in industrial scenario for enabling improvement in Leanness, thereby enabling organizations to achieve competitiveness among other organizations. Also, VSM helped the managers of (HANSEN DRIVES LIMITED) to visualize the wastes occurring in the organization and the future possibility of reducing/eliminating them. Finally, it is concluded that the lean manufacturing tools and techniques will be implemented in all kinds of manufacturing industries to improve their performance and also their products efficiency.

\section{REFERENCES}

1. Andreas and Fredrik (2011), "Lean Manufacturing at Volvo truck production Australia," Master thesis, Master of Science Programme," Vol. 12 (3), pp-29-36.

2. Bill and John( 2009), "Lean Manufacturing Training Minnesota Technology, Inc. (MTI) and West Central
Initiative (WCI)," west central Minnesota, Moorhead, MN 56560, pp 652-661.

3. Clinton and Hollis (2012), "Lean Manufacturing Ahead on the road lean with Ultra Source: Order Entry, Planning, Engineering, Purchasing, Facilities, and Quality Assurance," Ultra Source, 22 Clinton Drive, Hollis, NH 03049, pp- 503-512.

4. Donovan and Jenny (2014), "Lean Manufacturing Excellence: Successful implementation of organizational change in operations instead of short term cost reduction efforts," Orthopedics Inc, Vol - 12,pp: 261-274.

5. Fawaz (2015), "Lean Manufacturing Tools and Techniques in the process Industry for the successful implementation of lean," International journal of materials forum, Vol. 12, pp: 5214-5223.

6. George and Anthony (2016), "Lean Kaizen - A simplified approach to process improvements," Second edition, AJournal of process control pp: 1127-1132.

7. Herman (2016), "The Application, Utilization, and level of value adding of selected Lean Manufacturing Techniques", Progress of Taguchi journals, pp 25132520.

8. Jerry (2013), "Lean Principles: Implementation of lean practices in modern manufacturing industries", Utah Manufacturing Extension Partnership, pp: 4929 - 4933.

9. 9. R. Sundaran, A.N.Balaji (2014), "A Review on Lean Manufacturing Implementation Techniques", Procedia Engineering Pages 1875-1885.

10. Gupta, Shaman \& Jain, Sanjiv. (2013) “A literature review of lean manufacturing", International Journal of Management Science and Engineering Management 01 IOI/sp .825074.

11. Pirraglia, A., Saloni, D., van Dyk, H. (2009), "Status of lean manufacturing implementation on secondary wood industries including residential, cabinet, millwork, and panel markets," Bio Resources 4 (4), pp: 1341-1358.

12. Mehany MSHM (2017), "Lean construction principles past and present - a business model consistency," Journal of production control engineering, pp: 0149-0153.

13. Denish B.Modi, Hemant(2018), "Examining the interaction between lean and sustainability principles in the management process of AEC industry," Assessment of tool Manufacturing Journal, vol 12(6),pp: 212-220.

14. S Muhamad Mohd Razali, S Hamouda Abdel(2016), "Scope and impact of implementing lean principles \& practices in shipbuilding International Conference on Marine Technology, proceedings 226-233.

15. D'Antonioa, Joel Sauza Bedollaa, Paolo Chiabert(2016), "A novel methodology to integrate Manufacturing Execution Systems with the lean manufacturing approach," Journal of production and control charts, vol.2, pp: 367-378.

16. William Faulkner, Fazleena Badurdeen (2017), "Sustainable Value Stream Mapping (Sus-VSM): methodology to visualize and assess manufacturing sustainability performance," Review of Anova analysis Journal, pp: 2301-2312.

17. Falah Abu, Hamed Gholami, Muhamad Zameri(2014), "The implementation of lean manufacturing in the furniture industry: A review and analysis on the motives, barriers, challenges, and the applications," Journal of systematic lean production Flow," pp: 563-574.

18. Barth, H., Melin, M. (2018), “A Green Lean approach to global competition and climate change in the agricultural sector - a Swedish case stud,”. J. Clean. Prod. Vol. 204, pp: 183-192.

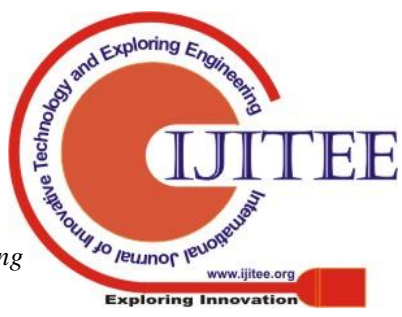


19. Sri Kollaa, Meysam Minufekra, Peter Plappera (2016), "Deriving essential components of lean and industry 4.0 assessment model for manufacturing SMEs 20," J integrated Manufacturing, Vol.3, pp: 1532-1546.

20. Abualfaraa, W.A., Salonitis, K., Al-Ashaab (2017), "Improving Sustainability of Manufacturing Systems Through Integrated Sustainable Value Stream Mapping Tool - Conceptual Framework," Journal of cleaner production, vol.3, pp: 2654-2673.

21. Gao, J., El Souri, M., Keates, S. (2015), "Impact on integration of Lean Manufacturing and Six Sigma in various applications - a review," 15th Int. Conf. Manuf. Res. Inc. 32nd Natl. Conf. Manuf. $\mathrm{http} / / 0102 / / \mathrm{io.22.423546.}$

22. M.L. Emiliani (2016), "Origins of lean management in America The role of Connecticut businesses by in origins of lean management in America," J lean concepts, pp: 221-228.

23. K. Hemanand, D. Amuthuselvan (2016), "Improving productivity of Manufacturing division using lean Concepts and development," Journal of product manufacturing, vol. 23 (6), pp: 714-720.

24. G. Muthukumaran, V. S. K .Venkatachalapathy, K. Pajaniradja (2018), "Implementation of a lean six sigma approach in the Manufacturing Sector: a systematic literature review," IOSR Journal of Mechanical and Civil Engineering (IOSR-JMCE) e- ISSN: 2278-1684 Volume 7, pp 4798-4804.

\section{AUTHOR PROFILE}

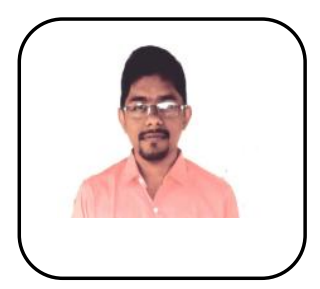

Mr. G. Yuvaraj, M.E., (Ph.D.), is working as an Assistant Professor at Easwari Engineering College, Chennai. Having six years of teaching experience, published nine indexed journals, also filed 7 patents filed under his credits. His areas of Interest is Materials \& Design.

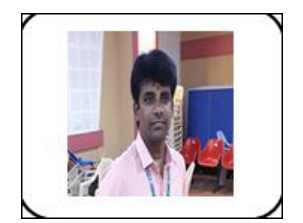

Mr. K. Giritharan, M.E., (Ph. D) is working as an Assistant Professor at Easwari Engineering College, Chennai. Having six years of teaching experience, published four indexed journals, under his credits. His areas of Interest is Materials \& Characterization.

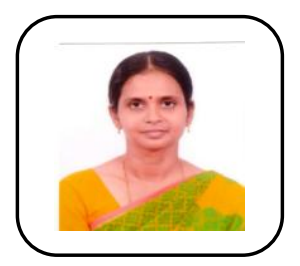

Mrs. K. Radhika, M. Tech., (Ph.D.), is working as an Assistant Professor at Easwari Engineering College, Chennai. Having ten years of teaching experience, published four International Journals. Her Areas of Interest is Materials \&Manufacturing.

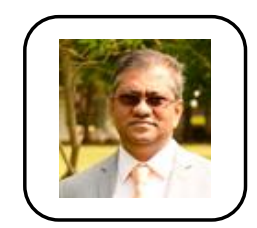

Dr. R. S. Kumar, M. Tech (IIT-D), Ph.D., FIE. $\mathrm{He}$ is working as an Principal of Easwari Engineering College, Chennai. For his credits, he published more than 250+ Indexed Journals Expert team member of National Board of Accreditation (NBA) for evaluating Programs of highly conversant with Academic Administration, have worked in Industry, R\&D and Academia was an entrepreneur and can identify profitable venture, very conversant with AICTE, NBA regulations and Accreditation process.

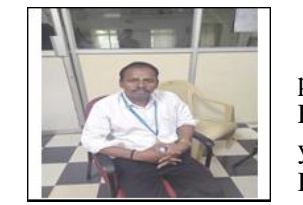

Dr. R. Ramadoss, M.E., Ph. D. is working as an professor of Mechanical Engineering at Easwar Engineering College, Chennai. He is having 21 years of teaching experience and 9 years of Research Experience in the areas of MetalForming. He had published 15 indexed journals. 